\title{
Improvement of fucosylated oligosaccharides synthesis by $\alpha-L$-fucosidase from Thermotoga maritima in water-organic cosolvent reaction system
}

\section{Mónica Robles-Arias}

Universidad Autonoma Metropolitana

Mariano García-Garibay

Universidad Autonoma Metropolitana

Sergio Alatorre-Santamaría

Universidad Autonoma Metropolitana

Salvador R Tello-Solís

Universidad Autonoma Metropolitana

Francisco Guzmán-Rodriguez

Universidad Autonoma Metropolitana

Lorena Gómez-Ruiz

Universidad Autonoma Metropolitana

Gabriela Rodríguez-Serrano

Universidad Autonoma Metropolitana

Alma Cruz-Guerrero ( $\nabla$ aec@xanum.uam.mx )

Universidad Autonoma Metropolitana Iztapalapa https://orcid.org/0000-0002-9686-2267

\section{Research Article}

Keywords: Fucosylated oligosaccharides, Fucosidase, Thermotoga maritima, aw, Organic solvents

Posted Date: April 29th, 2021

DOl: https://doi.org/10.21203/rs.3.rs-433850/v1

License: @ (i) This work is licensed under a Creative Commons Attribution 4.0 International License.

Read Full License

Version of Record: A version of this preprint was published at Applied Biochemistry and Biotechnology on July 26th, 2021. See the published version at https://doi.org/10.1007/s12010-021-03628-3. 


\section{Abstract}

The effects of water activity $\left(\mathrm{a}_{\mathrm{w}}\right), \mathrm{pH}$, and temperature on transglycosylation activity of $a$-L-fucosidase from Thermotoga maritima in the synthesis of fucosylated oligosaccharides were evaluated using different water - organic cosolvent reaction systems. The optimum conditions of transglycosylation reaction were the $\mathrm{pH}$ range between 7 and 10 , and temperature $90-95^{\circ} \mathrm{C}$. The addition of organic cosolvent decreased $a$-L-fucosidase transglycosylation activity in the following order: acetone $>$ dimethyl sulfoxide (DMSO) > acetonitrile $(0.51>0.42>0.18 \mathrm{mM} / \mathrm{h})$. However, the presence of DMSO and acetone enhanced enzyme-catalyzed transglycosylation over hydrolysis as demonstrated by the obtained transglycosylation/hydrolysis rate $\left(r_{T / H}\right)$ values of 1.21 and 1.43 , respectively. The lowest $r_{T / H}$ was calculated for acetonitrile (0.59), though all cosolvents tested improved the transglycosylation rate in comparison to a control assay (0.39). Overall, the study allowed the production of fucosylated oligosaccharides in water-organic cosolvent reaction media using $\alpha$-L-fucosidase from Thermotoga maritima as biocatalyst.

\section{Introduction}

Although highly abundant, human milk oligosaccharides (HMOs) are unique to human breast milk (10$15 \mathrm{~g} / \mathrm{L}$ ). They are widely known to play an important role in infant health by acting as prebiotics, modulators of gut motility, as well as they prevent enteric infections by blocking the adhesion of pathogenic bacteria [1, 2]. Chemical structures of HMOs follow a similar blueprint, for example, 3fucosyllactose can be formed when the hydroxyl group at C-3 of glucose at the reducing end of a lactose molecule is substituted by fucose while the most abundant 2'-fucosyllactose is obtained by the substitution of the hydroxyl group at C-2 of galactose [3].

In vivo biosynthesis of fucosylated oligosaccharides is catalyzed by specific transferases found in the Golgi apparatus of the mammary alveolar cells [4]. Since these enzymes are difficult to express and purify, as well as require expensive nucleotide-activated substrates, which add to the high cost of their production, their usage for the in vitro synthesis of fucosylated oligosaccharides is limited $[5,6]$. In contrast, glycosidases with transfucosylation activity like a-L-fucosidases (E.C. 3.2.1.51), are more available, relatively inexpensive with broad substrate specificity which is an advantageous characteristic in the synthesis of fucosylated oligosaccharides $[7,8]$. Under conventional conditions, fucosidases inherently catalyze the glycosidic bond hydrolysis [6]. However, when an acceptor molecule other than water is present the reaction media, it can attack the nucleophilic glycosyl-enzyme intermediate, and the transglycosylation reaction can proceed. The most recent reports have described successful protocols to obtain fucosylated oligosaccharides in the $a$-L-fucosidase assisted enzymatic reactions [9-12].

Owing to the fact that fucosidase-catalyzed synthesis of carbohydrates can be controlled kinetically, it has been possible to shift reaction equilibrium in favour of transglycosylation by manipulating reaction conditions [13]. The implemented strategies rely on the suppression of water activity $\left(a_{w}\right)$ in the media by 
either the addition of high concentrations of acceptor substrate [14] or the incorporation of organic cosolvents [15-17].

The main limitation to these approaches lies in the fact that enzymes may show lower activity in the presence of organic cosolvents compared to an aqueous medium while solubility of non-polar substrates and products is increased $[13,16]$. However, successful applications of miscible organic solvents in enzymatic reactions, such as dimethyl sulfoxide (DMSO) [18, 19], acetone [20,21] or acetonitrile [22] have been reported.

Thus, this work aimed at studying the effects of water-miscible organic solvents in the reaction system on transglycosylation activity of $a$-L-fucosidase from Thermotoga maritima to produce fucosylated oligosaccharides.

\section{Materials And Methods}

\section{Material}

4-nitrophenil- $\alpha$-L-fucopyranoside ( $p N P$-Fuc), 4-nitrophenol ( $p N P)$, 2'-fucosyllactose, D-lactose and Lfucose were purchased from Sigma-Aldrich (St. Louis MO, USA), sodium monophosphate, sodium diphosphate, $\mathrm{NaOH}$, acetone, acetonitrile and DMSO were purchased from J.T. Baker (Mexico State, Mexico). Recombinant $a$-L-fucosidase from Thermotoga maritima (E.C. 3.2.1.51) was acquired from Megazyme (Leinster, Ireland) at a concentration of $5 \mathrm{U} / \mathrm{mL}(2.6 \mathrm{U} / \mathrm{mg})$ in $3.2 \mathrm{M}$ ammonium sulphate and diluted 1:1000 (v/v) in $0.1 \mathrm{M}$ phosphate buffer at the corresponding pH. Milli-Q ${ }^{\circledR}$ water (Merck, Germany) was used throughout all experiments.

\section{a-L-Fucosidase activity assay}

$a$-L-Fucosidase activity assay was carried out for $10 \mathrm{~min}$ at $60^{\circ} \mathrm{C}$. Briefly, $50 \mu \mathrm{L}$ of $a$-L-fucosidase from $T$. maritima was added to $450 \mu \mathrm{L}$ of $p \mathrm{NP}$-Fuc $(3.5 \mathrm{mM})$ in phosphate buffer $(0.1 \mathrm{M}, \mathrm{pH}$ 8) and the reaction progress was analyzed every min. The reaction was stopped by adding $50 \mu \mathrm{L}$ of $\mathrm{NaOH}(1 \mathrm{M})$. Released $p N P$ was quantified by measuring absorbance (Shimadzu UV-1800, Tokyo, Japan) at $410 \mathrm{~nm}$. One unit of $\alpha$-L-fucosidase is defined as the amount of enzyme required to release $1 \mathrm{mmol}$ of $p \mathrm{NP}$ under the assay conditions.

\section{Synthesis of fucosylated oligosaccharides}

Enzymatic synthesis of fucosylated oligosaccharides was performed in phosphate buffer $(0.1 \mathrm{M}, \mathrm{pH} 8)$ for $120 \mathrm{~min}$ at $90^{\circ} \mathrm{C}$. The reaction mixture consisted of $a$-L-fucosidase $(0.0065 \mathrm{U} / \mathrm{mL}), p N P$-Fuc $(3.5 \mathrm{mM})$ as a donor substrate, and D-lactose $(438 \mathrm{mM})$ as an acceptor substrate. The reaction progress was analyzed every 30 min until stopped by adding $50 \mu \mathrm{L}$ of $\mathrm{NaOH}(1 \mathrm{M})$. The synthesized fucosylated oligosaccharides were quantified as described in section "Carbohydrate quantification". Released $p N P$ was quantified by measuring absorbance (Shimadzu UV-1800, Tokyo, Japan) at $410 \mathrm{~nm}$. 


\section{Effects of $\mathrm{pH}$ and temperature on transglycosylation activity of $a-\mathrm{L}-$ fucosidase}

The effect of $\mathrm{pH}$ on transglycosylation activity was determined in the $\mathrm{pH}$ range from 5 to 10 for $1 \mathrm{~h}$ at 60 ${ }^{\circ} \mathrm{C}$. Briefly, $50 \mu \mathrm{L}$ of $\alpha$-L-fucosidase $(0.0065 \mathrm{U} / \mathrm{mL})$ from $T$. maritima was added to $400 \mu \mathrm{L}$ of phosphate buffer $(0.1 \mathrm{M})$ containing $p N P$-Fuc $(3.5 \mathrm{mM})$ and D-lactose $(438 \mathrm{mM})$. The reaction progress was analyzed at $10,20,40$ and 60 min until stopped by adding $50 \mu \mathrm{L}$ of $\mathrm{NaOH}(1 \mathrm{M})$. The synthesized fucosylated oligosaccharides were quantified as described in section "Carbohydrate quantification". The transglycosylation activity was reported as the initial enzyme rate (Vo), expressed as concentration of the synthetized fucosylated oligosaccharides (mM) per minute. In a similar way, the effect of temperature on transglycosylation activity was determined. Experiments were carried out in a temperature range from 60 to $95^{\circ} \mathrm{C}$. The conversion yield was defined as the ratio of the synthesized fucosylated oligosaccharides to the initial concentration of donor substrate ( $p N P-F u c)$

\section{Estimation of $a_{w}$}

The $a_{w}$ values of the reaction system consisting of organic cosolvent and water at different ratios were estimated by a combination of the models reported by Bell et al. [23] and García-Garibay et al. [24]. The solvents employed were DMSO, acetone and acetonitrile.

\section{Effect of $a_{w}$ on the stability and hydrolytic activity of $a-L-$ fucosidase}

The effect of $\mathrm{a}_{\mathrm{w}}$ on enzyme stability was evaluated by the addition of organic cosolvent to the reaction system during $180 \mathrm{~min}$ at $60^{\circ} \mathrm{C}$. The test solvents were acetone $\left(a_{w} 0.97\right)$, acetonitrile $\left(a_{w} 0.96\right)$ or DMSO $\left(a_{w}\right.$ 0.99). Briefly, $50 \mu \mathrm{L}$ of $a$-L-fucosidase was mixed with $10 \mu \mathrm{L}$ of cosolvent and $40 \mu \mathrm{L}$ of phosphate buffer $(0.1 \mathrm{M}, \mathrm{pH} 8)$. Reaction progress was monitored every $30 \mathrm{~min}$. The enzyme activity was measured spectrophotometrically through the release of $p N P$ as already described. Residual hydrolytic activity was determined as the percentage of enzyme activity compared to control.

The effect of $\mathrm{a}_{\mathrm{w}}$ on the $\alpha$-L-fucosidase hydrolytic activity was evaluated by varying the volume of cosolvent in phosphate buffer $(0.1 \mathrm{M}, \mathrm{pH} 8)$. The reactions were carried out at $60^{\circ} \mathrm{C}$ for $10 \mathrm{~min}$. In brief, $50 \mu \mathrm{L}$ of $\alpha$-L-fucosidase from T. maritima was added to the reaction mixture containing $3.5 \mathrm{mM} p \mathrm{NP}$-Fuc, and different concentrations of test cosolvents in the reaction volume of $450 \mu \mathrm{L}$ as specified in Table 1 . The reaction was monitored every min until stopped by adding $50 \mu \mathrm{L}$ of $\mathrm{NaOH}(1 \mathrm{M})$. The hydrolytic activity was measured spectrophotometrically through the release of $p N P$ as already described. Residual hydrolytic activity was determined as the percentage of enzyme activity compared to control.

\section{Effect of organic media on the transglycosylation reaction}

The effect of acetone $\left(\mathrm{a}_{\mathrm{w}} 0.97\right)$, acetonitrile $\left(\mathrm{a}_{\mathrm{w}} 0.96\right)$ and DMSO $\left(\mathrm{a}_{\mathrm{w}} 0.99\right)$ on the $a$-L-fucosidase transglycosylation activity was evaluated for $180 \mathrm{~min}$ at $60^{\circ} \mathrm{C}$. Reaction volume of $450 \mu \mathrm{L}$ was kept constant while varying the organic cosolvent concentration in phosphate buffer $(0.1 \mathrm{M}, \mathrm{pH} 8)$ as specified in Table 1. The reaction mixture consisted of $50 \mu \mathrm{L}$ of $a$-L-fucosidase from T. maritima $(0.0065 \mathrm{U} / \mathrm{mL})$, 
pNP-Fuc $(3.5 \mathrm{mM})$ and D-lactose $(438 \mathrm{mM})$. The reaction progress was analyzed every 30 min until stopped by adding $50 \mu \mathrm{L}$ of $\mathrm{NaOH}(1 \mathrm{M})$. The synthesized fucosylated oligosaccharides were quantified by HPLC as described in section "Carbohydrate quantification". Released $p N P$ was quantified by measuring the absorbance at $410 \mathrm{~nm}$. The rate of transglycosylation to hydrolysis $\left(\mathrm{r}_{\mathrm{T} / / \mathrm{H}}\right)$ was expressed as the concentration ratio of the synthetized fucosylated oligosaccharides to the released $p N P$.

\section{Carbohydrate Quantification}

The quantification of the synthesized fucosylated oligosaccharides and the released fucose was performed on the HPLC (LabAlliance, State College, PA, USA) with an ion-exclusion column Rezex RNOOligosaccharides $\mathrm{Na}^{+}(4 \%)(60 \times 10 \mathrm{~mm}$; particle size $12 \mu \mathrm{m})$ (Phenomenex; Amstelveen, Netherlands) and oven temperature of $75^{\circ} \mathrm{C}$. The HPLC was equipped with a SOFTA 300 S light scattering detector (Chrom Tech, Minnesota, USA) with a nitrogen flow of $62.5 \mathrm{psi}$, spray chamber temperature of $10^{\circ} \mathrm{C}$ and a drift tube temperature of $45^{\circ} \mathrm{C}$.

Samples were filtered through $0.22 \mu \mathrm{m}$ Millipore Durapore membranes prior to assay by HPLC and were eluted with Milli-Q water at a flow rate of $0.3 \mathrm{~mL} / \mathrm{min}$. A calibration curve of $2^{\prime}$-fucosyllactose was used to estimate the amount of the product formed. Additionally, a standard 2'-fucosyllactose, D-lactose and Lfucose were used to determine their retention times and identify the reaction products.

\section{Statistical Analysis}

All experiments were performed in triplicate and results are reported as a mean value \pm standard deviation. For statistical analysis, the statistical software IBM SPSS Statistic version 25.0 for Windows (IBM, New York, USA) was used to carry out a one-way analysis of variance (ANOVA) followed by the Tukey's test for comparing all pairs of groups. A $p$ value of 0.05 was considered statistically significant.

\section{Results And Discussion}

\section{Synthesis of fucosylated oligosaccharides}

The synthesis of fucosylated oligosaccharides was carried out using $p N P$-Fuc and D-lactose as donor and acceptor substrates, respectively. Fig 1a shows a typical HPLC chromatogram of transglycosylation products. Retention time of the obtained fucosylated oligosaccharide $(7.7 \mathrm{~min})$ coincided with that of 2'fucosyllactose standard (Fig 1b). In addition, Fig 1a reveals the presence of fucose and fucosylated oligosaccharides which is indicative that the enzyme catalyzed both the hydrolysis of $p$ NP-Fuc and transglycosylation, respectively.

More detailed observations of the reaction progress of typical transglycosylation reaction are shown in Fig 2. The highest concentration of fucosylated oligosaccharide $(0.76 \mathrm{mM})$ was detected after $60 \mathrm{~min}$. As can be observed, in parallel to the $p$ NP-Fuc hydrolysis, some of the released fucose was enzymatically transferred to lactose leading to the formation of fucosylated oligosaccharide while the remaining fucose 
was observed as free fucose in the reaction medium. Similar results have been described by other authors Lezyk et al. [10] reported a conversion rate of $0.23 \mathrm{mM} / \mathrm{h}$ in the synthesis of 2'-fucosyllactose using $\alpha$-L-fucosidase from T. maritima at a concentration of $0.51 \mu \mathrm{g} / \mathrm{mL}$, using $20 \mathrm{mM} p N P$-Fuc and 25 $\mathrm{mM}$ D-lactose at pH 5.0 and $30^{\circ} \mathrm{C}$. In another study, $\alpha$-L-fucosidase from T. maritima was employed at a concentration of $0.13 \mu \mathrm{g} / \mathrm{mL}$ to catalyze the synthesis of fucosyllactose, using $3.5 \mathrm{mM} p N P$-Fuc and 584 $\mathrm{mM}$ D-lactose at $\mathrm{pH} 5.9$ and $60^{\circ} \mathrm{C}$. The highest conversion rate achieved in these conditions was 0.29 $\mathrm{mM} / \mathrm{h}$ [9]. The conversion yield obtained in this study $(0.76 \mathrm{mM} / \mathrm{h})$ was higher than those reported by the aforementioned authors and using lower concentration of a-L-fucosidase $(0.013 \mu \mathrm{g} / \mathrm{mL})$.

\section{Effect of $\mathrm{pH}$ and temperature on the $a$-L-fucosidase transglycosylation activity}

Fig 3a shows the transglycosylation activity of $\alpha$-L-fucosidase from T. maritima. The highest activity was found in the $\mathrm{pH}$ range from 7 to 10 since no statistically significant difference was calculated for this $\mathrm{pH}$ interval $(p<0.05)$. Additionally, the enhanced transglycosylation activity was observed with the increasing $\mathrm{pH}$ from 5 to 8 , which resulted in the improved yields from 6.07 to $40.67 \%$, respectively. The obtained results are in accordance with other studies that investigated optimum reaction conditions of glycosidases from thermophilic sources. Wu et al. [25] reported improved yields in galactooligosaccharides (GOS) synthesis catalyzed by $\beta$-glycosidase from Sulfolobus solfataricus by changing $\mathrm{pH}$ from 4 to 6 . Likewise, two recombinant $\beta$-glycosidases expressed in E. coli (F441Y and F359Q) performed better at pH 6.5 than 4. In another study, Ji et al. [26] also observed that pH 6 was optimum for the GOS production catalyzed by a recombinant $\beta$-galactosidase from $T$. maritima expressed in $E$. coli in contrast to $\mathrm{pH}$ above 7 at which the enzyme activity was remarkably reduced. In another study, the improved yields of GOS were linked to the $\mathrm{pH}$ rise from 5 to 5.5 using $\beta$-mannosidase from Pyrococcus furiosus as a catalyst [27].

It is noteworthy that conversion yields of enzymatic transglycosylation increase in alkaline media. Sulzenbacher et al. [28] and Tarling et al. [29] suggested that $\mathrm{pH}$ changes of the reaction medium affected the $\mathrm{pK}_{\mathrm{a}}$ of a key amino acid involved in the catalysis. Abdul Manas et al. [13] concluded that ionization of this key amino acid was a determinant factor in favoring interactions with either water, which would lead to hydrolysis, or sugar acceptor resulting in the improved yield of transglycosylation product as observed in the present work.

As for the effect of temperature, the highest transglycosylation activity was observed in the range of $90^{\circ} \mathrm{C}$ to $95^{\circ} \mathrm{C}$ (Fig. 3b). The reaction yield at $95^{\circ} \mathrm{C}$ was three times higher than that obtained at $60{ }^{\circ} \mathrm{C}(32.01$ and $10.58 \%$ respectively). Similar effect was observed by Zeuner et al. [30] who reported a sixfold increase of the reaction yield (from 0.9 to $5.4 \%$ ) in the $N$-acetyllactosamine synthesis catalyzed by $\beta$ galactosidase from Pyrococcus furiosus when the temperature was raised from 40 to $90^{\circ} \mathrm{C}$. In another work, the conversion yield of GOS in the presence of $\beta$-galactosidase from Bacillus circulans was three times greater at $60^{\circ} \mathrm{C}$ than at $25^{\circ} \mathrm{C}(5$ and $15 \mathrm{~g} / \mathrm{L}$, respectively) [31]. Moreover, the research group of Fourage et al. [32] reported a 2.6-fold increase of reaction yield in the $p$ NP-Fuc-Fuc synthesis (from 16 to 
42\%) catalyzed by $\beta$-glycosidase from Thermus thermophilus, in response to the temperature rise from 37 to $75^{\circ} \mathrm{C}$.

\section{Estimation of $a_{w}$ in the reaction system}

Since water distribution in the reaction medium of enzymatic process tends to maintain balance with all the components of such system, the thermodynamic parameter $\mathrm{a}_{\mathrm{w}}$ is the best variable to determine water availability in mixed-solvents systems. The $a_{w}$ values of media containing test cosolvents were evaluated, according to a model previously described for enzymatic reactions in organic media [23, 24] and reported in Fig. 4 and Table 1. As can be seen, the test solvents affected the $a_{w}$ of reaction system differently. Since the obtained isotherms followed the same pattern as those reported by Bell et al. [23] and Cruz-Guerrero et al. [20] the data were deemed valid.

\section{Effect of $a_{w}$ on the hydrolytic activity and stability of a-L-fucosidase}

By changing $\mathrm{a}_{\mathrm{w}}$ of the reaction medium, it is possible to increase production yield of fucosylated oligosaccharides. Prior to the experiment, enzyme stability was examined in a test medium with a variable $a_{w}$ value obtained by the addition of a water-miscible cosolvent. The three organic solvents and the corresponding $a_{w}$ of the reaction medium were acetone $\left(a_{w} 0.97\right)$, acetonitrile $\left(a_{w} 0.96\right)$, and DMSO $\left(a_{w} 0.99\right)$. As shown in Fig. $5 a$, no difference in enzyme activity was observed for the reaction systems tested $(p<0.05)$ during the reaction course, and the enzyme retained around $76 \%$ of its activity after 180 minutes in comparison to control. Pyeon et al. [33] reported that the recombinant $\beta$-glycosidase from Microbulbifer thermotolerans displayed 93,79 and $20 \%$ of its activity after incubation in acetone, $\left(a_{w}\right.$ 0.97), DMSO ( $\left.\mathrm{a}_{\mathrm{w}} 0.98\right)$ and acetonitrile $\left(\mathrm{a}_{\mathrm{w}} 0.96\right)$, respectively. In their previous study [34] a recombinant chitinase MtCh509 from Microbulbifer thermotolerans was reported to retain up to $100 \%$ its activity in media with DMSO as an additive at $\mathrm{a}_{\mathrm{w}}$ of 0.99 and 0.96 , whereas in the presence of acetone and acetonitrile the enzyme activity decreased remarkably. As a general rule, it is assumed that thermophilic enzymes possess rigid structures that directly contribute to their apparent resistance to organic solvents [35]. In this context, the preserved enzymatic activity of a-L-fucosidase used in this work in the presence of the three cosolvents can be explained in a similar manner.

As can be seen in Fig. 5b, residual hydrolytic activity of a-L-fucosidase exceeded $100 \%$ in the presence of acetone $\left(a_{w} 0.97,0.95,0.93\right)$ and acetonitrile $\left(a_{w} 0.96,0.93,0.91\right)$. Nevertheless, at the $a_{w}$ values lower than 0.91 the enzyme activity declined. In case of DMSO as cosolvent in the reaction system at $a_{w} 0.99$, no significant improvement of enzymatic activity was observed in comparison to the control assay $(p<0.05)$, but at lower $\mathrm{a}_{\mathrm{w}}$ the $\alpha$-L-fucosidase performance was negatively affected. Conversely, MallekFakhfakh and Belghith [36] described no changes in the activity of $\beta$-glucosidase from Talaromyces thermophilus in the presence of DMSO at $\mathrm{a}_{\mathrm{w}}$ of 0.97 while further drop of $\mathrm{a}_{\mathrm{w}}$ to 0.91 caused remarkable enzyme deactivation. Furthermore, Jiang et al. [37] reported that the activity of xylanase B from $T$. maritima was unaffected by the addition of DMSO $\left(a_{w} 0.96\right)$. The solvent impact on enzyme activity is 
mostly correlated with Log $P$ or another measure of its polarity rather than a combination of factors such as the dielectric constant, the dipole moment, the ability to form hydrogen bonds, as well as denaturation capability. Taken together, these properties determine how the solvent affects the way reactants interact with the active site of the enzyme [38]. The extremophile $\alpha$-L-fucosidase from T. maritima employed in this work displayed higher resistance in the presence of different concentrations of organic solvents. This is an attractive feature for their usage in many industrial processes.

\section{Effect of organic media on the $\alpha$-L-fucosidase transglycosylation activity}

Based on the results from previous experiments, $a$-L-fucosidase from T. maritima showed high stability and activity in the reaction media containing acetone $\left(\mathrm{a}_{\mathrm{w}} 0.97\right)$, acetonitrile $\left(\mathrm{a}_{\mathrm{w}} 0.96\right)$ and DMSO $\left(\mathrm{a}_{\mathrm{w}}\right.$ 0.99). Thus, these cosolvents were studied in the enzymatic synthesis of fucosylated oligosaccharides. Fig. 6a demonstrates the reaction course of transglycosylation using different cosolvent in a reaction system. The highest conversion rate was achieved in the medium with the addition of acetone followed by DMSO and acetonitrile (acetone $>$ DMSO $>$ acetonitrile $=0.51>0.42>0.18 \mathrm{mM} / \mathrm{h}$ ).

On the contrary, Trincone et al. [39] reported improved yields in the synthesis of $\beta$-D-glucopyranoside disaccharides and trisaccharides catalyzed by a mutant $\beta$-glycosidase from S. solfataricus (Ss- $\beta$ glyE387G) when acetonitrile was added to the reaction system. In other studies, a hyperthermophilic $\beta$ glycosidase was used in the synthesis of GOS in water - acetone system at $a_{w}$ of 0.47 and the highest conversion rate was $0.051 \mu \mathrm{mol} / \mathrm{mL}$ [20]. In the case of porcine liver $\alpha$-L-fucosidase employed to produce fucopyranosides in the reaction system with DMSO, the extended reaction time was needed, by approximately $9 \%$, to afford the same yield as in conventional media [19].

The effect of water activity and cosolvents on the $\mathrm{r}_{\mathrm{T} / \mathrm{H}}$ ratio was also evaluated in the present study (Fig. $6 \mathrm{~b})$. In the presence of acetone, $a$-L-fucosidase showed higher transglycosylation than hydrolytic activity which corresponded to the $r_{T / H}$ value greater than 1 , with a maximum recorded at $30 \mathrm{~min}\left(r_{T / H} 1.43\right)$. In case of DMSO, the highest $r_{T / H}$ was obtained after 120 min and equaled to 1.21. Among the three cosolvents, acetonitrile presented the $\mathrm{r}_{\mathrm{T} / \mathrm{H}}$ below 1 , indicating on the predominant hydrolytic activity rather than transglycosylation. Overall, the addition of cosolvents, such as acetone and DMSO, to the reaction media improved kinetic equilibrium towards enzymatically catalyzed transglycosylation, as indicated by their maximal $\mathrm{r}_{\mathrm{T} / \mathrm{H}}$ values when compared to the control (0.39).

Similar results were reported by Li et al. [40], who observed a decrease in the transglycosylation activity of a commercially available collection of thermophilic glycosidases (CLONEZYME) in the reaction media containing acetonitrile at $\mathrm{a}_{\mathrm{w}}$ of 0.88 . On the contrary, Li et al. [41] showed that addition of DMSO as a cosolvent at $a_{w}$ of 0.94 improved the yield of daidzein transglycosylation product by $14 \%$ (from 39 to $44.47 \%$ ). The reaction was catalyzed by a recombinant maltosyl transferase from $T$. maritima expressed in E. coli. Additionally, Baek et al. [42] reported higher yield of transglycosylation products in a reaction catalyzed by maltogenic amylase from a Thermus strain when acetone was added as a cosolvent to the reaction media. The authors observed suppressed hydrolytic activity. 


\section{Conclusions}

The gathered results indicate that $a$-L-fucosidase from $T$. maritima can catalyze the synthesis of fucosylated oligosaccharides in water-organic cosolvent media. The best results were observed for acetone $(0.51 \mathrm{mM} / \mathrm{h})$. Moreover, the addition of acetone or DMSO to the medium shifted the reaction equilibrium favoring transglycosylation over the enzyme-assisted hydrolysis as the calculated $\mathrm{r}_{\mathrm{T} / \mathrm{H}}$ values of 1.43 and 1.21 , respectively, were higher compared to the value recorded for the control assay $(0.39)$. Finally, it is possible that the fucosylated oligosaccharides synthesized in this study have biological functions, like human milk oligosaccharides, and can be used either for clinical applications or as an additive in infant formulas.

\section{Declarations}

Funding. This work was supported by Consejo Nacional de Ciencia y Tecnología (grant number 592532) and Universidad Autónoma Metropolitana.

Conflicts of interest. The authors declare that they had no conflict of interest.

Authors contribution R-A. M: Methodology, formal analysis and investigation, writing-original draft preparation. A-S. S: Formal analysis and investigation, writing - review and editing. G-G. M.: Conceptualization, formal analysis and investigation, funding acquisition, resources. G-R. F.: Methodology. G-R. L.: Formal analysis and investigation, writing - review and editing. R-S. G.: Funding acquisition, resources. C-G.A.: Conceptualization, formal analysis and investigation, writing-original draft preparation, funding acquisition, resources, supervision.

\section{Compilance with Ethical Standards}

Ethics approval. This article does not contain any studies with human participants or animals performed by any of the authors.

Consent to participate. Not applicable

Consent for publication. Not applicable

\section{References}

1. Bode, L. (2016). The functional biology of human milk oligosaccharides. Early Human Development, 91(11), 619-622. https://doi.org/10.1016/j.earlhumdev.2015.09.001

2. Zehra, S., Khambati, I., Vierhout, M., Mian, M. F., Buck, R. and Forsythe, P. (2018). Human milk oligosaccharides attenuate antigen-antibody complex induced chemokine release from human intestinal epithelial cell lines. Journal of Food Science, 83(2), 499-508. https://doi.org/10.1111/1750-3841.14039 
3. Bode, L. and Jantscher-Krenn, E. (2012). Structure-Function Relationships of Human Milk Oligosaccharides. Advances in Nutrition, 3(3) 383S-391S. https://doi.org/10.3945/an.111.001404

4. Gabrielli, O., Zampini, L., Galeazzi, T., Padella, L., Santoro, L., Peila, C., Giuliani, F., Bertino, E., Fabris, C. and Coppa, G. V. (2011). Preterm milk oligosaccharides during the first month of lactation. Pediatrics, 128(6), e1520-e1531. https://doi.org/10.1542/peds.2011-1206

5. Romero-Téllez, S., Lluch, J. M., González-Lafont, À. and Masgrau, L. (2019) Comparing hydrolysis and transglycosylation reactions catalyzed by Thermus thermophilus $\beta$-glycosidase. A combined MD and QM/MM study. Frontiers in Chemestry, 7, 200. https://doi.org/10.3389/fchem.2019.00200

6. Zeuner, B. and Meyer, A. S. (2020). Enzymatic transfucosylation for synthesis of human milk oligosaccharides. Carbohydrate Research, 493. https://doi.org/10.1016/j.carres.2020.108029

7. Van Rantwijk, F., Woudenberg-van Oosterom, M. and Sheldon, R. A. (1999). Glycosidase-catalysed synthesis of alkyl glycosides. Journal of Molecular Catalysis B: Enzymatic, 6(6), 511-532. https://doi.org/10.1016/S1381-1177(99)00042-9

8. Wan, L., Zhu, Y., Zhang, W. and Mu, W. (2020). a-L-Fucosidases and their applications for the production of fucosylated human milk oligosaccharides. Applied Microbiology and Biotechnology, 104, 5619-5631. https://doi.org/10.1007/s00253-020-10635-7

9. Guzmán-Rodríguez, F., Alatorre-Santamaría, S., Gómez-Ruiz, L., Rodríguez-Serrano, G., García-Garibay, M. and Cruz-Guerrero, A. (2018). Synthesis of a fucosylated trisaccharide via transglycosylation by $a$ L-fucosidase from Thermotoga maritima. Applied Biochemestry and Biotechnology, 186(3), 681-691. https://doi.org/10.1007/s12010-018-2771-x

10. Lezyk, M., Jers, C., Kjaerulff, L., Gotfredsen, C. H., Mikkelsen, M. D. and Mikkelsen, J. D. (2016). Novel $a$-L-fucosidases from a soil metagenome for production of fucosylated human milk oligosaccharides. PLOS ONE, 11(1), 1-18. https://doi.org/10.1371/journal.pone.0147438

11. Liu, P., Zhang, H., Wang, Y., Chen, X., Jin, L., Xu, L. and Xiao, M. (2020). Screening and characterization of an a-L-fucosidase from Bacteroides fragilis NCTC9343 for synthesis of fucosyl$\mathrm{N}$-acetylglucosamine disaccharides. Applied Microbiology and Biotechnology. 104(18), 7827-7840. https://doi.org/10.1007/s00253-020-10759-w

12. Zeuner, B., Muschiol, J., Holck, J., Lezyk, M., Gedde, M. R., Jers, C., Mikkelsen, J. D. and Meyer, A. S. (2018). Substrate specificity and transfucosylation activity of GH29 $\alpha$-L-fucosidases for enzymatic production of human milk oligosaccharides. New Biotechnology, 41, 34-45. https://doi.org/10.1016/j.nbt.2017.12.002

13. Abdul Manas, N. H., Md. Illias, R. and Mahadi, N. M. (2018). Strategy in manipulating transglycosylation activity of glycosyl hydrolase for oligosaccharide production. Critical Reviews in Biotechnology, 38(2), 272-293. https://doi.org/10.1080/07388551.2017.1339664

14. Mangas-Sánchez, J. and Adlercreutz, P. (2015). Enzymatic preparation of oligosaccharides by transglycosylation: A comparative study of glucosidases. Journal of Molecular Catalysis B: Enzymatic, 122, 51-55. https://doi.org/10.1016/j.molcatb.2015.08.014 
15. Hansson, T., Andersson, M., Wehtje, E. and Adlercreutz, P. (2001). Influence of water activity on the competition between $\beta$-glycosidase-catalysed transglycosylation and hydrolysis in aqueous hexanol. Enzyme and Microbial Technology, 29(8-9), 527-534. https://doi.org/10.1016/S01410229(01)00421-5

16. Khatami, S., Ashtiani, F. Z., Bonakdarpour, B. and Mehrdad, M. (2014). The enzymatic production of lactulose via transglycosylation in conventional and non-conventional media. International Dairy Journal. 34(1), 74-79. https://doi.org/10.1016/j.idairyj.2013.07.010

17. Zeuner, B., Jers, C., Mikkelsen, J. D. and Meyer, A. S. (2014). Methods for improving enzymatic transglycosylation for synthesis of human milk oligosaccharide biomimetics. Journal of Agricultural and Food Chemestry, 62(40), 9615-9631. https://doi.org/10.1021/jf502619p

18. Farkas, E., Thiem, J. and Ajisaka, K. (2000). Enzymatic synthesis of fucose-containing disaccharides employing the partially purified a-L-fucosidase from Penicillium multicolor. Carbohydrate Research, 328(3), 293-299. https://doi.org/10.1016/S0008-6215(00)00113-0

19. Svensson, S.C. and Thiem, J. (1990) Purification of $a$-L-fucosidase by C-glycosylic affinity chromatography, and the enzymic synthesis of $a$-L-fucosyl disaccharides. Carbohydrate Research, 200, 391-402. https://doi.org/10.1016/0008-6215(90)84205-9

20. Cruz-Guerrero, A.E, Gómez-Ruiz, L., Viniegra-Gónzalez G., Bárzana, E. and García-Garibay, M. (2005). Influence of water activity in the synthesis of galactooligosaccharides produced by a hyperthermophilic $\beta$-glycosidase in an organic medium. Biotechnolgy and Bioengineering, 93(6), 1123-1129. https://doi.org/10.1002/bit.20824

21. Vera, C., Guerrero, C., Wilson, L. and Illanes, A. (2017). Optimization of reaction conditions and the donor substrate in the synthesis of hexyl- $\beta$-D-galactoside. Process Biochemestry, 58, 128-136. https://doi.org/10.1016/j.procbio.2017.05.005

22. Akiba, S., Yamamoto, K. and Kumagai, H. (1999). Transglycosylation activity of the Endo- $\beta-1,4-$ glucanase from Aspergillus niger IF031125 and its application. Journal of Bioscience and Bioengineering, 87(5), 576-580. https://doi.org/10.1016/S1389-1723(99)80117-0

23. Bell, G., Janssen, A. E. and Halling, P. J. (1997). Water activity fails to predict critical hydration level for enzyme activity in polar organic solvents: Interconversion of water concentrations and activities. Enzyme and Microbial Technology, 20(6), 471-477. https://doi.org/10.1016/S0141-0229(96)00204-9

24. García-Garibay, M., López-Munguía, A. and Bárzana, E. (2000). Effect of $\beta$-galactosidase hydration on alcoholysis reaction in organic one-phase liquid systems. Biotechnology and. Bioengineering, 70(6), 647-653. https://doi.org/10.1002/1097-0290(20001220)70:6<647::AID-BIT6>3.0.C0;2-Z

25. Wu, Y., Yuan, S., Chen, S., Wu, D., Chen, J. and Wu, J. (2013). Enhancing the production of galactooligosaccharides by mutagenesis of Sulfolobus solfataricus $\beta$-galactosidase. Food Chemestry, 138(2-3), 1588-1595. org/10.1016/j.foodchem.2012.11.052

26. Ji, E. S., Park, N. H. and Oh, D. K. (2005). Galacto-oligosaccharide production by a thermostable recombinant $\beta$-galactosidase from Thermotoga maritima. World Journal of Microbiology and Biotechnology, 21(5), 759-764. https://doi.org/10.1007/s11274-004-5487-8 
27. Hansson, T, Kaper, T., van der Oost, J., De Vos, W. and Adlercreutz, P. (2001). Improved oligosaccharide synthesis by protein engineering of $\beta$-glucosidase CelB from hyperthermophilic Pyrococcus furiosus. Biotechnology and Bioengineering, 73(3), 203-210. https://doi.org/10.1002/bit.1052

28. Sulzenbacher, G., Bignon, C., Nishimura, T., Tarling, C. A., Withers, S. G., Henrissat, B. and Bourne, Y. (2004). Crystal structure of Thermotoga maritimaa-L-fucosidase: Insights into the catalytic mechanism and the molecular basis for fucosidosis. Journal of Biological Chemestry, 279(13), 13119-13128. https://doi.org/10.1074/jbc.M313783200

29. Tarling, C. A., He, S., Sulzenbacher, G., Bignon, C., Bourne, Y., Henrissat, B. and Withers, S. G. (2003). Identification of the catalytic nucleophile of the family $29 a$-L-Fucosidase from Thermotoga maritima through trapping of a covalent glycosyl-enzyme intermediate and mutagenesis. Journal of Biological Chemestry, 278(48), 47394-47399. https://doi.org/10.1074/jbc.M306610200

30. Zeuner, B., Nyffenegger, C., Mikkelsen, J. D. and Meyer, A. S. (2016). Thermostable $\beta$-galactosidases for the synthesis of human milk oligosaccharides. New Biotechnology, 33(3), 355-360. https://doi.org/10.1016/j.nbt.2016.01.003

31. Warmerdam, A., Boom, R. M. and Janssen, A. E. M. (2013) $\beta$-Galactosidase stability at high substrate concentrations. Springerp/us, 2(1), 402. https://doi.org/10.1186/2193-1801-2-402

32. Fourage, L., Dion, M. and Colas, B. (2000). Kinetic study of a thermostable $\beta$-glycosidase of Thermus thermophilus. Effects of temperature and glucose on hydrolysis and transglycosylation reactions. Glycoconjugate Journal, 17(6), 377-383. https://doi.org/10.1023/A:1007104030314

33. Pyeon, H. M., Lee, Y. S. and Choi, Y. L. (2019). Cloning, purification, and characterization of GH3 $\beta-$ glucosidase, MtBgl85, from Microbulbifer thermotoleransPeerJ, 7, e7106. https://doi.org/10.7717/peerj1106

34. Lee, H. J., Lee, Y. S. and Choi, Y. L. (2018). Cloning, purification, and characterization of an organic solvent-tolerant chitinase, MtCh509, from Microbulbifer thermotoleransBiotechnology for Biofuels, 17(1), 1-14. https://doi.org/10.1186/s13068-018-1299-1

35. Vieille, C. and Zeikus, G. J. (2001). Hyperthermophilic enzymes: sources, uses, and molecular mechanisms for thermostability. Microbiology and Molecualr Biology Reviews, 65(1), 1-43. https://doi.org/10.1128/MMBR.65.1.1-43.2001

36. Mallek-Fakhfakh, H. and Belghith, H. (2016). Physicochemical properties of thermotolerant extracellular $\beta$-glucosidase from Talaromyces thermophilus and enzymatic synthesis of cellooligosaccharides. Carbohydrate Research, 419, 41-50. https://doi.org/10.1016/j.carres.2015.10.014

37. Jiang, Z., Zhu, Y., Li, L., Yu, X., Kusakabe, I., Kitaoka, M., Hayashi, K.: Transglycosylation reaction of xylanase $B$ from the hyperthermophilic Thermotoga maritima with the ability of synthesis of tertiary alkyl $\beta$-D-xylobiosides and xylosides. Jornal of Biotechnology, 114(1-2), 125-134. https://doi.org/10.1016/j.jbiotec.2004.05.007

38. Bankova, E., Bakalova, N., Petrova, S. and Kolev, D. (2006). Enzymatic synthesis of oligosaccharides and alkylglycosides in water-organic media via transglycosylation of lactose. Biotechnology and 
Biotechnological Equipment, 20(3), 114-119. http://dx.doi.org/10.1080/13102818.2006.10817387

39. Trincone, A., Giordano, A., Perugino, G., Rossi, M. and Moracci, M. (2005). Highly productive autocondensation and transglycosylation reactions with Sulfolobus solfataricusChemBioChem, 6(8), 1431-1437. https://doi.org/10.1002/cbic.200400430

40. Li, J., Cheng, H. N., Nickol, R. G. and Wang, P. G. (1999). Enzymatic modification of hydroxyethylcellulose by transgalactosylation with $\beta$-galactosidases. Carbohydrate Research, 316(14), 133-137. https://doi.org/10.1016/S0008-6215(99)00041-5

41. Li, D., Park, J. H., Park, J. T., Park, C. S. and Park, K. H. (2004). Biotechnological production of highly soluble daidzein glycosides using Thermotoga maritimaJournal of Agricultural and Food Chemestry, 52(9), 2561-2567. https://doi.org/10.1021/jf035109f

42. Baek, J. S., Kim, M. J., Cha, H., Lee, H.S., Li, D., Kim, J.W., Kim, Y.R., Moon, T.W. and Park, K. (2003). Enhanced transglycosylation activity of Thermus maltogenic amylase in acetone solution. Food Science and Biotechnology, 12(6), 639-643.

\section{Table}

Table 1. $a_{w}$ values estimated at different solvent concentrations.

\begin{tabular}{ccccc}
\hline Solvent volume $(\mu \mathrm{L})$ & ${ }^{*}$ Buffer volume $(\mu \mathrm{L})$ & $\mathrm{a}_{\mathrm{w}}$ Acetone & $\mathrm{a}_{\mathrm{w}}$ Acetonitrile & $\mathrm{a}_{\mathrm{w}}$ DMSO \\
\hline 50 & 400 & 0.97 & 0.96 & 0.99 \\
100 & 350 & 0.95 & 0.93 & 0.96 \\
150 & 300 & 0.93 & 0.91 & 0.91 \\
200 & 250 & 0.91 & 0.90 & 0.83 \\
\hline 250 & 200 & 0.90 & 0.88 & 0.74 \\
\hline
\end{tabular}

* Phosphate buffer (0.1 M pH 8)

\section{Figures}




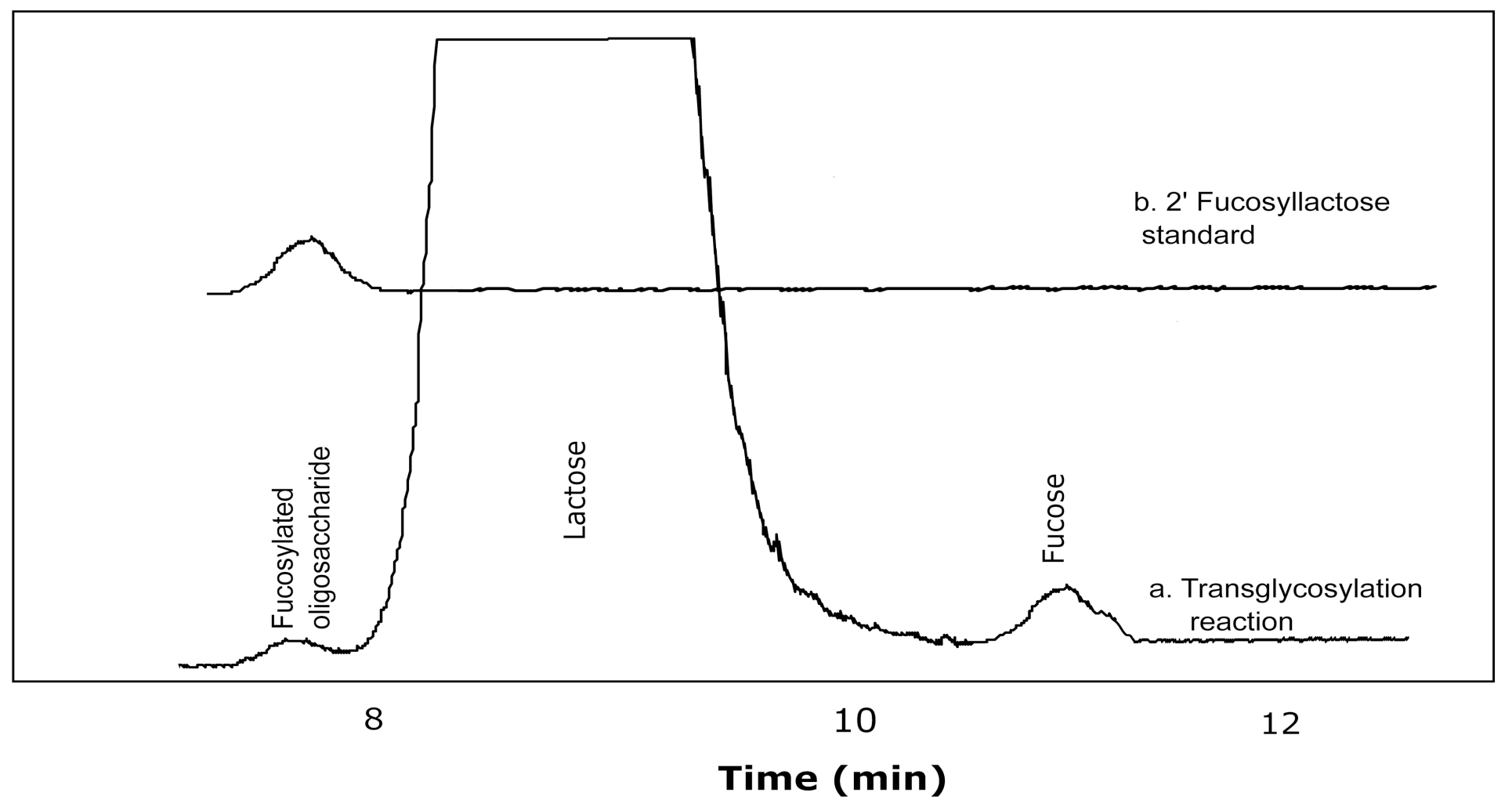

\section{Figure 1}

Typical Chromatograms obtained by HPLC from (a) sample of the transglycosylation reaction and (b) $2^{\prime}$ fucosyllactose standard. Transglycosylation reaction was performed at $90^{\circ} \mathrm{C}$ and $\mathrm{pH} 8$ by using 3.5 $\mathrm{mM}$ pNP-Fuc as the donor substrate, $438 \mathrm{mM}$ D-lactose as the acceptor substrate and $0.0065 \mathrm{U} / \mathrm{mL} \mathrm{a-L}-$ fucosidase. 


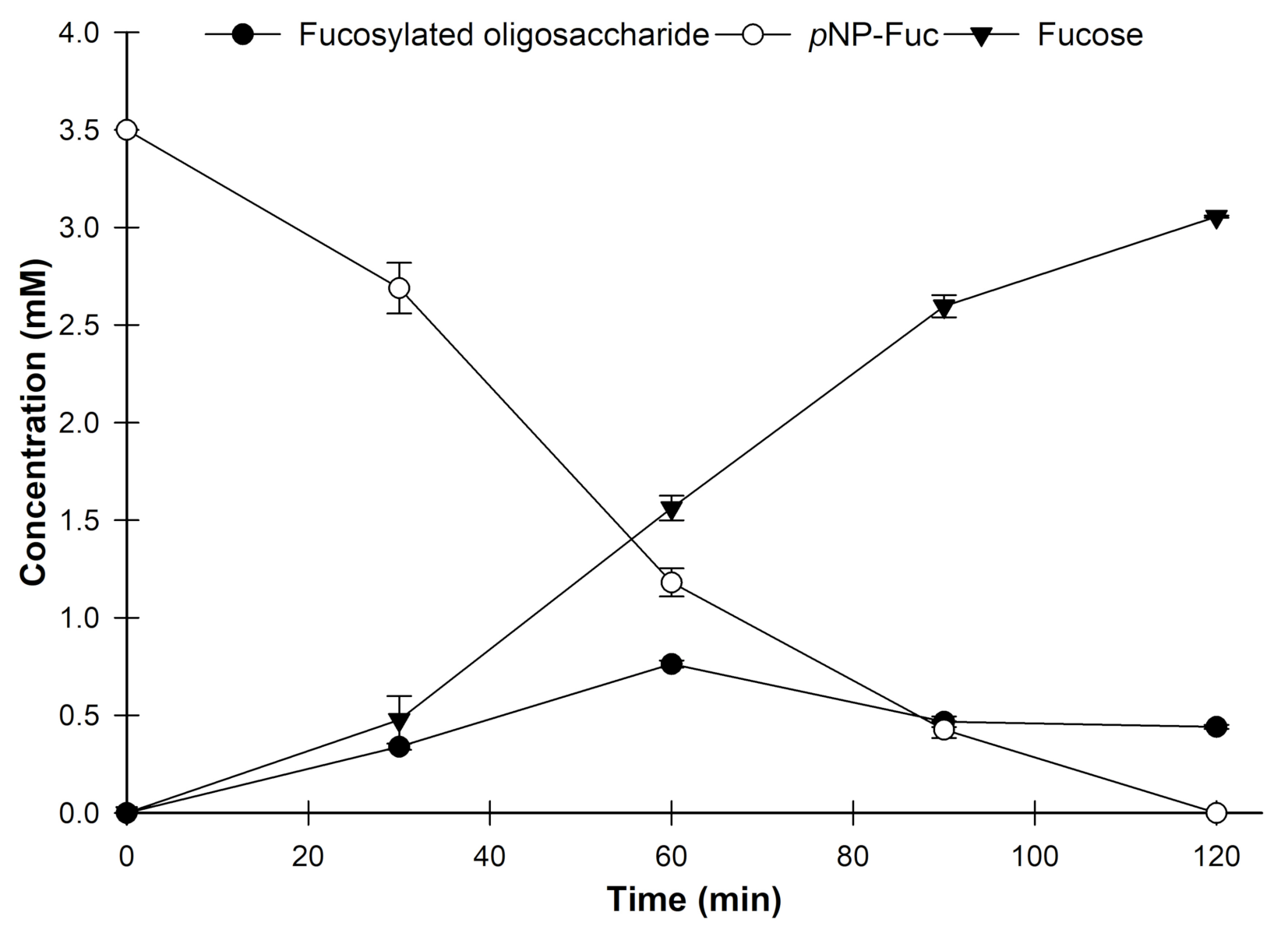

Figure 2

Kinetics of transglycosylation reaction catalysed by a-L-fucosidase from T. maritima. Reaction was performed at $90^{\circ} \mathrm{C}$ using $3.5 \mathrm{mM}$ pNP-Fuc as donor substrate, $438 \mathrm{mM}$ D-lactose as acceptor substrate and $0.0065 \mathrm{U} / \mathrm{mL}$ of a-L-fucosidase. All reacts were dissolved in $0.1 \mathrm{M}$ phosphate buffer at $\mathrm{pH} 8$. 
a

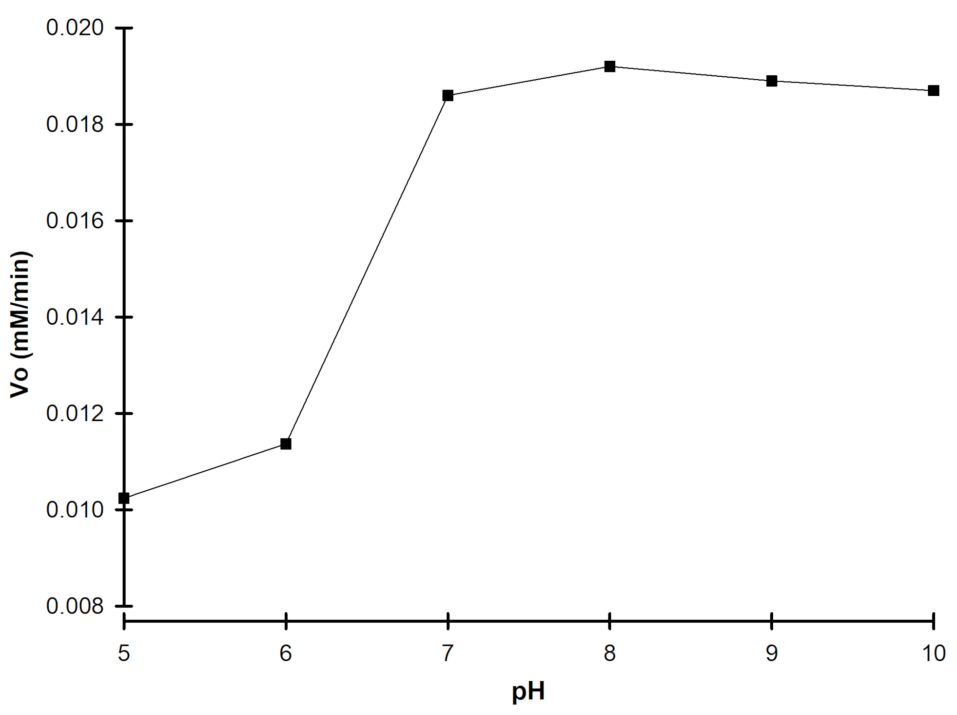

b

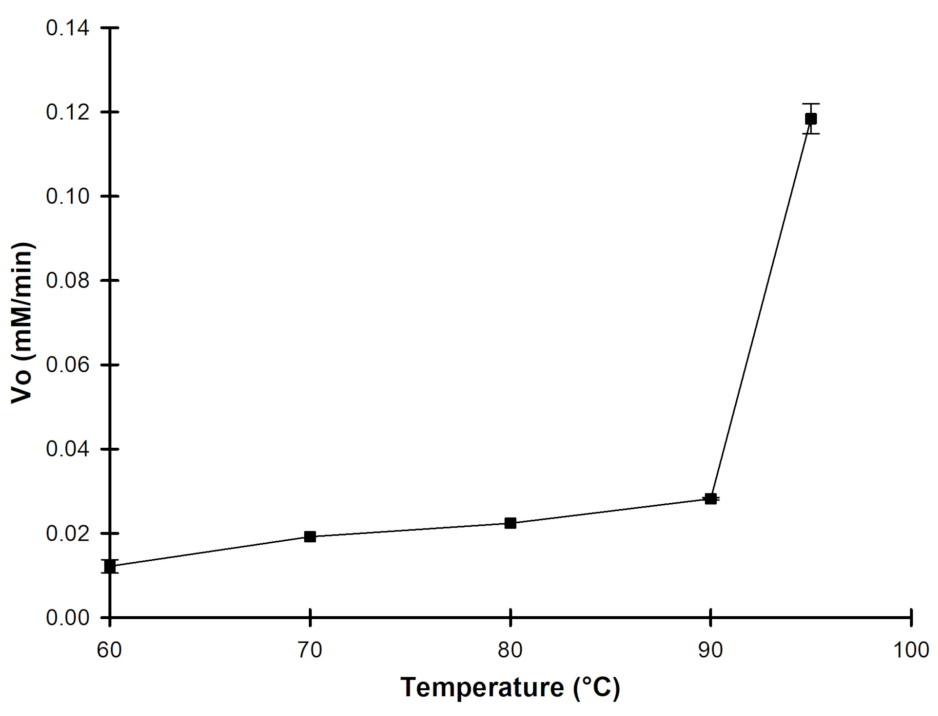

\section{Figure 3}

Effect of $\mathrm{pH}(\mathrm{a})$ and temperature (b) on the initial velocity of transglycosylation activity of a-L-fucosidase from T. maritima. The effect of $\mathrm{pH}$ on the initial reaction velocity of the transglycosylation activity was performed at different $\mathrm{pH}$ and $60^{\circ} \mathrm{C}$ by using pNP-Fuc $3.5 \mathrm{mM}$, lactose $438 \mathrm{mM}$ and $0.0065 \mathrm{U} / \mathrm{mL}$ of a-Lfucosidase. Initial reaction velocity of the transglycosylation activity. The effect of temperature was evaluated under the same conditions but at $\mathrm{pH} 8$ and different temperature. Error bars represent the standard deviation of the mean of triplicates. 


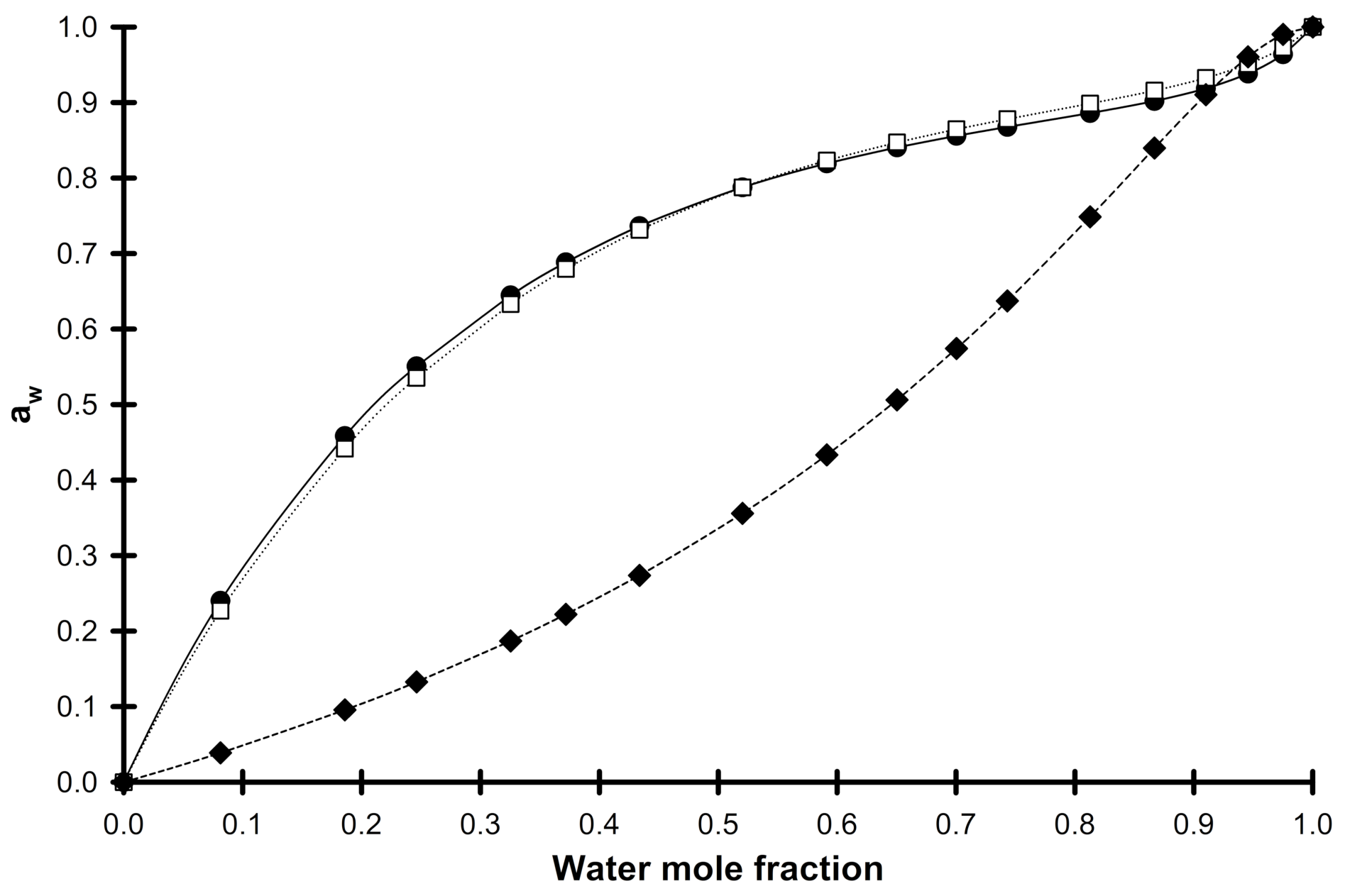

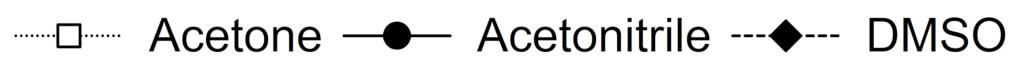

Figure 4

Sorption isotherms for Acetone $(\square)$, Acetonitrile $(\bullet)$ and DMSO $(\diamond)$. The aw values at different ratios were estimated by a combination of the models reported by Bell et al. [23], and García-Garibay et al. [24]. 

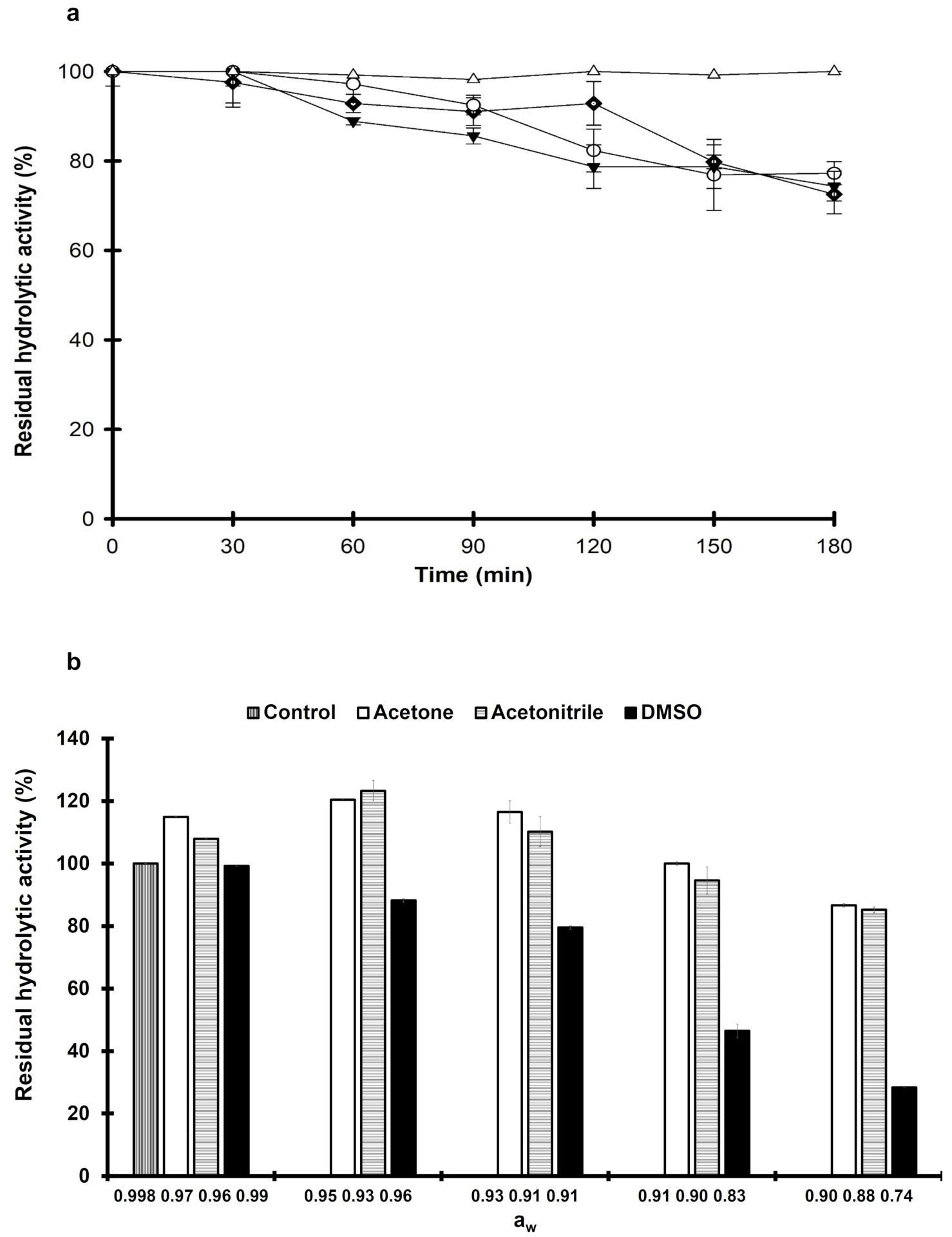

\section{Figure 5}

Stability(a) and Residual hydrolytic activity (b) of a-L-fucosidase from T. maritima. The time course of change in the stability of the a-L-fucosidase was determined by incubating $0.013 \mathrm{U} / \mathrm{mL}$ a-L-fucosidase from T. maritima at $60{ }^{\circ} \mathrm{C}$ in phosphate buffer $(0.1 \mathrm{M}, \mathrm{pH}$ 8) as control (aw 0.998$)$ and buffer-organic solvent; acetone (aw 0.97), acetonitrile (aw 0.96) and DMSO (aw 0.99) during $180 \mathrm{~min}: \triangle$ control, acetone, acetonitrile and DMSO. To observe the residual hydrolytic activity reaction was performed 
at $60{ }^{\circ} \mathrm{C}$ and using either acetone, acetonitrile or DMSO as a cosolvent, $3.5 \mathrm{mM}$ pNP-Fuc and 0.0065 $\mathrm{U} / \mathrm{mL}$ a-L-fucosidase from T. maritima. Control assay was performed in absence of cosolvent under the same conditions and considered as $100 \%$ of the residual hydrolytic activity. Error bars represent the standard deviation of the mean of triplicates.

a

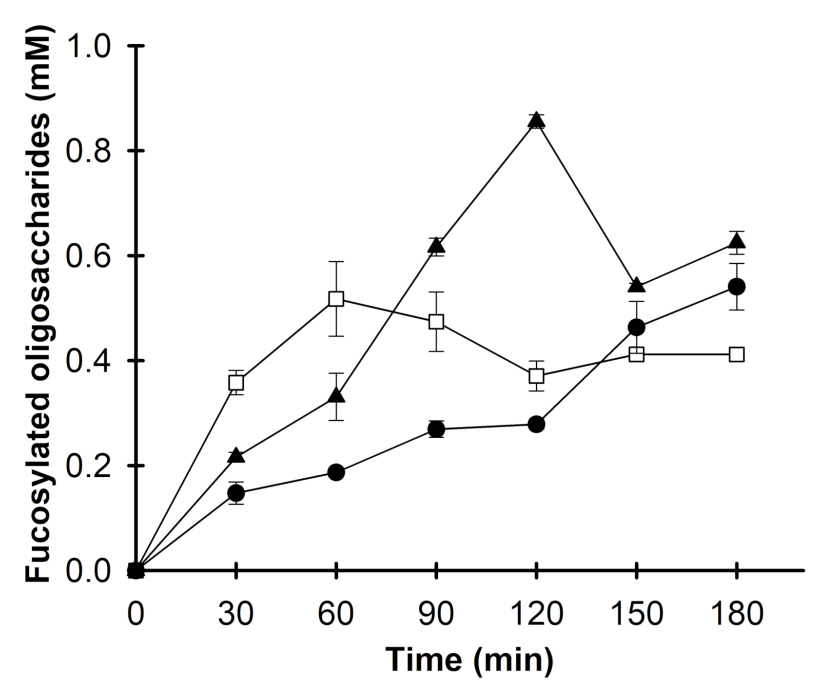

b

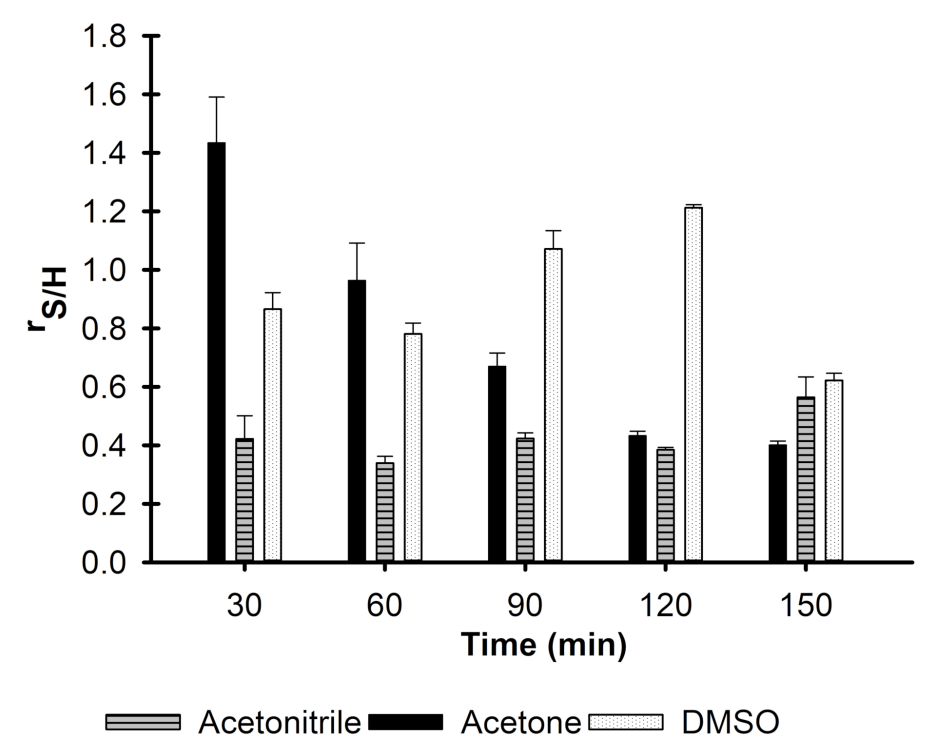

\section{Figure 6}

Effect of the solvents on the (a) synthesis of fucosylated oligosaccharides and (b) $\mathrm{rS} / \mathrm{H}$ ratio catalyzed by a-L-fucosidase from T. maritima. Reaction was performed at $60^{\circ} \mathrm{C}$ during 180 min either with acetone (aw 0.97), acetonitrile (aw 0.96) and DMSO (aw 0.99) as cosolvent in the reaction medium, pNP-Fuc as the donor, $438 \mathrm{mM}$ D-lactose as the acceptor and $0.0065 \mathrm{U} / \mathrm{mL}$ of a-L-fucosidase from T. maritima: acetone, acetonitrile and $\Delta$ DMSO. Error bars represent the standard deviation of the mean of triplicate. 